TEI

JOURNAL OF THE
Journal of the Text Encoding Initiative

Issue 7| November 2014

Reaching out, Opting in

\title{
Editorial Introduction to Issue 7 of the Journal of the Text Encoding Initiative
}

Susan Schreibman

\section{(2) OpenEdition \\ Journals}

Electronic version

URL: http://journals.openedition.org/jtei/1046

DOI: 10.4000/jtei.1046

ISSN: 2162-5603

Publisher

TEl Consortium

Electronic reference

Susan Schreibman, «Editorial Introduction to Issue 7 of the Journal of the Text Encoding Initiative », Journal of the Text Encoding Initiative [Online], Issue 7 | November 2014, Online since 01 January 2014 connection on 20 April 2019. URL : http://journals.openedition.org/jtei/1046 ; DOI : 10.4000/jtei.1046 
TEI

OURNAL OF THE

CODING INITIATIVE

Journal of the Text Encoding Initiative

Issue 7 | 2014

Reaching out, Opting in

Editorial Introduction to Issue 7 of the Journal of the Text Encoding Initiative

Susan Schreibman

revues.org

Publisher

TEl Consortium

Electronic version

URL: http://jtei.revues.org/1046

ISSN: 2162-5603

Electronic reference

This text was automatically generated on 13 November 2014 . 


\title{
Editorial Introduction to Issue 7 of the Journal of the Text Encoding Initiative
}

\author{
Susan Schreibman
}

1 This is one of the smallest issues of the Journal of the Text Encoding Initiative, but its size belies its importance. This is the first issue of the Journal that had an open call for papers. Up to now, issues were either selected papers from the TEI conference (issues 1,2 4, and 6) or issues on a theme (issue 3: TEI and Linguistics and issue 5: TEI Infrastructures).

2 This open call elicited articles that touch upon contemporary meta concerns within the community; evaluating and teaching TEI, the very premises of our encoding methods, and the uses and reuses of TEI-encoded texts. This issue also marks the end of my tenure as the Journal's Founding Editor-in-Chief.

3 Two of the articles, Sarah L. Pfannenschmidt and Tanya E. Clement's "Evaluating Digital Scholarship: Suggestions and Strategies for the Text Encoding Initiative" and Stella Dee's "Learning the TEI in a Digital Environment" speak to concerns that mark the ongoing success of the Text Encoding Initiative and its growing practice of use.

Opportunities for training in the TEI, both philosophically and methodologically, are not new. I took my first training at the Oxford Summer School in the late 1990s. As far as I remember, it was the only place to learn TEI, at least on this side of the Atlantic. I myself taught TEI (in the bad old days of SGML) for the first time in Ireland in 1999. Training opportunities were rare enough then. Today, the situation is entirely different as Dee's article documents.

5 The question today is not so much if training is available, but which course should a researcher choose. But as Dee strongly suggests (and as I have personally heard throughout my years on the TEI Board and Council), there is also a greater role for the TEI Consortium itself in gathering, making available, and augmenting current offerings. Moreover, as Dee's article also documents, the training needs of the community are as varied as the uses to which researchers employ the TEI, both at introductory and advanced levels. 
Pfannenschmidt and Clement's article also works on a meta level. It deals with an issue that is becoming more urgent as more digital humanists are employed in traditional academic departments and are allowed to have their digital scholarship count towards promotion and tenure.

7 This article charts the issues involved in evaluating scholarship that has TEI-encoded text at its centre. It thoughtfully discusses the role (if any) that the TEI Consortium might play in this process. The article reflects the panoply of views of those who participated in the survey carried out by the authors as to what exactly is being evaluated when a work of digital scholarship based on a TEI-encoded text is being evaluated and who should do the reviewing. This article reminds us that evaluating digital scholarship should be a core scholarly concern, not simply for this community, but for the future of our disciplines as more and more scholarship utilizes the TEI as its primary knowledge representation system.

8 Desmond Schmidt's "Towards an Interoperable Digital Scholarly Edition" revisits issues that were amongst those first articulated by the "Poughkeepsie Principles": ${ }^{1}$ that of interoperability. Schmidt challenges some of the most fundamental design principles inherent in our methods of encoding, and hence creating digital scholarly editions. His propositions take into account the many new models of creating editions, from crowdsourcing to collaborative scholarship: something that the early designers of the TEI could barely imagine, let alone implement given the technologies at the time (and, indeed, throughout most of the TEI's existence).

Schmidt's thesis is provocative, but this challenge to current practice marks a maturation of the community: one in which dominant theoretical stances are so widespread that their very dominance invites new perspectives. This is a healthy sign of a healthy intellectual community.

10 And lastly, Daniel Carter's "A Design Methodology for Exploring and Communicating System Values and Assumptions" like Schmidt's article, deals with knowledge representation. But in Carter's case, he examines how the tools we use shape our encoding and hence our value systems. He also argues, like Schmidt, for a more flexible approach to TEI display, its reuse, and remediation.

11 Carter argues his case, not from the centre of TEI encoding practice, but from a periphery, that of a designer utilizing TEI texts and tools to explore design opportunities in imagining new futures for encoded text.

12 Taken together, these articles reflect not only issues central to digital scholarship today, but make important contributions to discussions and directions of the TEI's future.

13 This issue also marks the end of my tenure as Founding Editor-in-Chief of the Journal of the Text Encoding Initiative. This is the first issue that has not had guest editors which provides me with the opportunity to thank those who made the Journal such a success. Establishing a peer-review journal from scratch is an enormous effort: from establishing a peer-review body to encouraging one's peers to submit to an as yet untested publication. In an environment where the location of one's publication is as important (some might argue more important) than the article's content, getting one's peers to take a chance on a new journal is crucial.

14 This confidence developed early, due, in great measure, to the guest editors who cajoled and encouraged our peers to take a chance on this fledgling publication. And it has been gratifying to see how frequently articles that have appeared in the Journal have been 
cited (and cited in many languages), attesting to the international reach of the community and its official publication. There are over a thousand citations in Google Scholar: an amazing achievement for a journal so young.

But the journal would never have had such a smooth birth without the dedication of the first Managing Editor, Kevin S Hawkins, and Technical Editor, Markus Flatscher. Both were extremely generous with their time and talent, in which no matter was too big or too small to tackle, from line spacing in the final HTML output to designing the author's style guide in which issues such as to whether to capitalise to the $g$ in the TEI Guidelines was discussed at length (we opted for Guidelines with a capital G). Without their help, enthusiasm, and dedication, the Journal would not have flourished as it does now.

When the Journal was established by the TEI Board, it was decided that the Technical Editor, the Managing Editor, and the Editor-in-Chief would have staggered terms, so that the entire team would not rotate off at the same time. After one year, when Markus stepped down, Ron Van den Branden took his place. Ron has been a pleasure to work with, quietly and efficiently dealing with any text that came his way, transforming each one so that the quality of the Journal's presentation is superb.

When Kevin stepped down after two years as Managing Editor, I could not imagine anybody I would enjoy working with as much. But Martin Holmes filled that gap. He is what a General Editor seeks in a Managing Editor: somebody who is attentive to detail; who can juggle many balls but let none drop.

When Susie Lorand came on board as the Journal's copyeditor, my life was transformed. She is a treasure to work with, and has allowed us to standardise many of our practices. Tanya Clement served as Reviews Editor, but unfortunately had to step down before she was able to implement a reviews section.

My thanks also go to revues.org, who stepped in when the Consortium was looking for a publishing venue which had to be open access as well as accept TEI-encoded text. This is not exactly a ubiquitous publishing environment. At times our publishing needs pushed revues' publishing capability, but they dealt with each of our requests graciously and professionally, providing us with a platform that has responded to the community's needs.

I am delighted that I have been succeeded by John Walsh as Editor-in-Chief. I have no doubt that he will serve the community well and that the Journal will flourish under his watch.

21 And lastly, my thanks go to you, the TEI community, who have both submitted and reviewed articles, making the Journal the success it is. The TEI community is still not a large one, and many of you have reviewed more than your fair share of submissions. Your honesty, thoroughness, and thoughtfulness has been vital in achieving the very high quality of work published. 


\section{NOTES}

1. http://www.tei-c.org/Vault/ED/edp01.htm

\section{AUTHOR}

\section{SUSAN SCHREIBMAN}

Susan Schreibman is Professor of Digital Humanities, Maynooth University. 